\title{
DAKWAH TERAPETIK: SOLUSI ATAS PROBLEM MANUSIA MODERN
}

\author{
Muskinul Fuad
}

\begin{abstract}
:
In this modern era, human beings are facing various crisis or multidimensional problems. Material welfare following the development of science and technology does not easily give them real happiness. They have been the victims of globalization. In such condition, the role of $d a^{\prime} i$ as a "doctor" of the sick souls is really needed to recover the victims of globalization. Therapeutic $d a$ 'wa is an alternative solution of this serious problem. $D a$ 'wa with this approach is developed on the basis of religion's function as a therapy. This function requires deep study of therapeutic aspects in Islamic teachings. This effort can be seen from esoteric dimension of Islam.
\end{abstract}

Keywords:

tragedy of modern people, the role of a $d a^{\prime} i$, therapeutic da'wa

\section{Krisis Manusia Modern}

Globalisasi dan modernisasi, di samping telah membawa berkah kemajuan, diakui pula telah menimbulkan berbagai persoalan serius bagi kehidupan umat manusia. Manusia di jaman ini tengah menghadapi berbagai krisis atau penyakit secara multidimensi, baik aspek fisik, psikis, sosial, ekonomi, maupun spiritual. Dalam perspektif psikologi komunikasi,

\footnotetext{
* Penulis adalah Magister Agama UIN Sunan Kalijaga Yogyakarta dan Dosen tetap Jurusan Dakwah Sekolah Tinggi Agama Islam Negeri (STAIN) Purwokerto
}

KOMUNIKA, Vol. I No. 2 Juli-Desember 2007 
akibat kemajuan teknologi yang telah memudahkan pertukaran informasi yang begitu cepat, manusia modern akan mengalami apa yang disebut dengan banjir informasi. Kondisi ini dapat menjadi sumber stres yang kronis bagi setiap individu serta akan menyebabkan adanya "penyakit adaptasi", sebuah istilah yang ditujukan kepada orang yang mengalami ketidakmampuan dalam memahami dan menyesuaikan diri dengan lingkungan yang berubah begitu cepat. Dia tidak mampu bereaksi dan mengambil keputusan secara tepat atas problem dan tantangan yang mewarnai hidupnya. ${ }^{1}$

Yablonsky, sebagaimana dikutip oleh Jalaluddin Rakhmat (2003), menyatakan bahwa ciri lain yang tampak dari penyakit manusia modern, bahkan pasca modern, adalah terdapatnya gejala alienasi atau keterasingan diri. Individu dipisahkan dari pengalaman manusiawinya. Dia seolah menjadi mesin otomatis yang telah kehilangan spontanitas, kreativitas, dan individualitas. Perilaku dan perannya tidak berbeda dengan robot yang siap menjalankan perintah majikan yang menyetir dirinya melalui remote control. Dia bergerak secara monoton, nir-emosi, tanpa nilai, dan tanpa makna. Manusia robot menjalani aktivitas harian dari mulai bangun tidur, makan, bekerja, bercinta, menonton, berlibur, dan sebagainya secara ritual, penuh frustasi, serta membosankan. Penderitaan ini akan menimbulkan rasa permusuhan dan agresivitas.

Di sisi lain, masuknya teknologi komunikai secara masif telah pula mengakibatkan adanya beban psikologis yang berat. Oleh karena hampir semua pekerjaan ditangani teknologi, misalnya komputer, maka semakin banyak orang yang akan kehilangan pekerjaannya, PHK semakin kerap terjadi, sehingga terjadilah pengangguran di mana-mana. Kondisi ini selanjutnya akan melahirkan kesenjangan sosial, konflik, dan terjadinya keresahan sosial. Keresahan sosial akan melahirkan kejahatan, kekejaman, tindak kekerasan, histeria masa, dan penyakit sosial lainnya. ${ }^{2}$

Dalam bahasa yang berbeda, manusia modern oleh para pemikir muslim sering dikatakan sedang mengalami "tragedi". Istilah ini digunakan untuk menyebut krisis kejiwaan manusia modern. Secara material barangkali tidak dapat disangkal bahwa kemajuan ilmu pengetahuan dan

\footnotetext{
${ }^{1}$ Rakhmat, Jalaluddin, Islam Aktual, (Bandung : Mizan), 2003, hal . 68-69

${ }^{2}$ Ibid, hal. 70
} 
teknologi dalam berbagai bidang telah berhasil meningkatkan harkat manusia, namun secara hakiki tidak. Yang terjadi justru hal itu telah mengakibatkan kegelisahan, hilangnya makna hidup dan kehampaan nilainilai spiritual. Kebahagiaan yang diidam-idamkan oleh manusia modern bukannya tercapai, tetapi malah berganti dengan penderitaan yang tidak

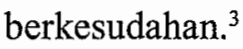

Gambaran tentang tragedi manusia modern di atas boleh jadi lebih diidentikkan dengan apa yang telah dialami oleh masyarakat Barat. Anggapan ini memang benar, karena masyarakat Baratlah yang terlebih dahulu ditimpa krisis peradaban. Akan tetapi, dengan adanya globalisasi, gejala yang sama telah dialami pula oleh masyarakat muslim yang sebagian besar dari mereka tinggal di belahan timur, termasuk Indonesia. Problem mental spiritual sebagai dampak modernisasi dapat dilihat dengan gamblang pada masyarakat Indonesia, utamanya di kota-kota besar seperti Jakarta. Fenomena seperti narkoba, bunuh diri, dan seks bebas adalah sajian rutin yang dapat kita nikmati lewat media masa dan seolah menjadi trend di negeri ini.

Dalam tinjauan Psikologi Agama, maraknya aliran sesat yang belakangan terjadi menurut hemat penulis secara tidak langsung turut pula menunjukkan betapa sakitnya masyarakat penganutnya, baik pemimpin maupun para pengikutnya. Dikatakan tidak langsung mengingat bahwa mereka boleh jadi memasuki aliran sempalan tersebut tidak karena adanya tuntutan ingin menjadi modern, tetapi lebih dikarenakan merupakan pelarian dari kondisi yang penuh stres serta frustasi akibat beratnya tantangan hidup. Dalam hal ini para pengikut aliran tersebut bisa dikatakan sebagai masyarakat korban- penderita ketidakmampuan akan tantangan modernitas. Berbeda halnya dengan sebagian besar masyarakat Barat dan sebagian kecil masyarakat Timur (baca: muslim) yang menjadi korban - pelaku, artinya mereka memang telah mengalami modernisasi dan mengalami kesuksesan material, tetapi kemudian sengsara secara mentalspiritual dan akhimya lari ke narkoba, bunuh diri, dan tindakan tidak sehat lainnya.

${ }^{3}$ Moh. Soleh \& Imam Musbikin, Agama Sebagai Terapi,(Yogyakarta: Pustaka Pelajar) 2005, hal. 36-37

KOMUNIKA, Vol. I No. 2 Juil-Desember 2007 
Beberapa faktor disinyalir secara kuat menjadi sumber penyebab potret buram tersebut. Beberapa diantaranya adalah meningkatnya pola hidup materialis, hedonis, individualis, dan egois. Pola hidup seperti inilah yang menjadi ciri masyarakat modern dan ini biasanya terdapat pada masyarakat yang hidupnya jauh dari agama. Mereka mengingkari kehidupan akhirat, sehingga tidak berfikir adanya kehidupan setelah di dunia ini. Tuhan dianggap sudah mati sehingga manusia merasa terbebas dari pertanggungjawaban atas segala perbuatannya di muka bumi. Istilah lain dari masyarakat model ini adalah masyarakat sekuler. Agama tidak perlu dilibatkan dalam kehidupan sehari-hari.

Kondisi yang demikian tentu menuntut adanya pemikiran, refleksi, dan peran aktif, baik itu dari para akademisi maupun para aktivis dakwah. Perlu dikaji lebih jauh bagaimana peran da'i dan model dakwah yang perlu dikembangkan menghadapi masyarakat yang telah sakit secara mental-spiritual, akibat menjadi korban globalisasi tersebut. Lebih jauh perlu dipikirkan pula upaya-upaya pencegahan agar masyarakat yang masih "sehat" tidak mengalami penderitaan atau sakit dalam menghadapi globalisasi. Tantangan untuk dapat mencapai kesuksesan secara material tidak lantas membuat umat muslim harus kehilangan kebahagiaan sejati yang berdimensi spiritual (ruhani). Menjadi modern dan maju tidak harus mengorbankan barang berharga yang dimiliki secara potensial oleh semua manusia, yaitu jiwa atau hati yang tenteram. Tulisan ini akan mencoba menawarkan sebuah konsep dakwah terapetik sebagai bahan kajian dalam pengembangan ilmu dakwah.

\section{Peran Da'i}

Korban-korban globalisasi telah bergelimpangan di berbagai penjuru dunia yang semakin sumpek dan sesak ini. Hal ini tentu membutuhkan penanganan dari kaum intelektual, termasuk para da'i. $\mathrm{Da}^{\prime} \mathrm{i}$, sebagai sosok pembawa misi Islam di bumi, dituntut untuk dapat menjadi pembimbing dan penyembuh bagi jiwa-jiwa yang sakit. Dia ibarat dokter jiwa yang harus menangani para pasien sebagai korban globalisasi dan modernisasi. Untuk itu, layaknya seorang dokter, para da'i, kyai, ustadz, dan ulama perlu melakukan diagnosis terhadap penyakit para pasiennya yang merupakan manusia-manusia yang hidup di jaman modern ini. Hasil 
diagnosis tersebut kemudian ditindaklanjuti dengan pemberian resep atau pengobatan yang diramu dari ajaran-ajaran Islam. Resep itu berupa pesanpesan dakwah yang sejuk dan bersifat terapetik (menyembuhkan). Para pasien yang telah berhasil disembuhkan oleh para da' $i$ tersebut kemudian mendapatkan perawatan lanjutan (kontrol) secara rutin. Dalam bahasa lain, perawatan ini berupa pembinaan rohani secara rutin baik secara individual maupun kelompok, dengan berbagai kegiatan seperti majlis ta'lim, home care ${ }^{4}$, konsultasi, dan sebagainya.

Da'i yang mampu berperan sebagaimana dokter jiwa di atas adalah da'i yang mampu memahami kebutuhan dan karakteristik psikologis umatnya. Di samping itu, karena sasarannya adalah pasien korban globalisasi, dia juga dituntut untuk mampu membaca serta memahami perkembangan dan tanda-tanda jaman. Dua kemampuan da'i ini, disamping didapatkan dari sumber ajaran pokok, Qur'an dan Sunnah Nabi, dapat pula didapatkan dari kajian ilmu-ilmu bantu seperti psikologi, kesehatan mental, sejarah, futurologi, dan rujukan lainnya.

Senada dengan perannya sebagai dokter jiwa, meminjam istilah dunia tarikat, para da'i dapat pula berperan sebagai mursyid, guru atau pembimbing spiritual. Para jama'ahnya diperlakukan sebagai murid yang sedang menempuh jalan spiritual (salik). Sang musryid akan membimbing para muridnya untuk mendaki tahapan-tahapan tertentu agar dapat menggapai ma'rifat kepada Allah, sebuah kebahagiaan sejati yang selama ini didambakan dan dicari-cari oleh manusia-manusia modern. Kecenderungan munculnya organisasi tarikat, training, atau kajian yang bercorak tasawuf di perkotaan, tempat tinggal manusia modern, dapat dikatakan merupakan garapan para da'i yang berposisi seperti mursyid. Hal ini sepadan dengan adanya gejala gandrungnya masyarakat barat. Kebanyakan dari mereka mungkin lari ke narkoba, tetapi tidak sedikit pula yang tertarik dan berbondong-bondong memasuki klub-klub yoga, meditasi, dan dunia mistik timur seperti Zen Budhisme dan ordo tarikat.

Dua peran da'i tersebut, yaitu sebagai dokter jiwa dan pembimbing spiritual, secara umum dapat diambil oleh para da'i konvensional (agamawan) yang biasa disebut dengan kyai, syaikh, ustadz, ulama, atau

${ }^{4}$ Artinya da'i di jaman modern ini boleh jadi dapat melakukan kunjungan ke rumah jama'ahnya untuk berdakwah. Dalam dunia konseling dikenal adanya layanan home visit atau dalam dunia kesehatan dikenal adanya dokter keluarga. 
mubaligh. Akan tetapi hal itu dapat sedikit pula diperankan atau dirangkap oleh para da'i yang memiliki background intelektual atau profesi seperti psikiater, dosen, guru, psikolog, konselor, dan lainnya. Dengan pemahaman keagamaan yang memadai, bukan tidak mungkin kiprah mereka dapat melebihi peran da'i dengan background pesantren dan perguruan tinggi agama. Poinnya, da'i dengan ciri keulamaan dan intelektualitas akan menjadi kombinasi yang pas serta semakin dibutuhkan oleh umat pada jaman ini.

Satu hal pokok yang perlu ditekankan ialah bahwa da'i yang dapat berperan sebagai penyembuh adalah mereka yang telah menempuh $A t h$ -Thariq Al-Isyraqy (jalur pencerahan batin)..$^{5}$ Jalur inilah yang telah ditempuh oleh kaum sufi yang sebenarnya juga ditempuh oleh para Nabi. Artinya da'i juga harus menjadi pengamal tasawuf, baik secara falsafy, amaly, maupun akhlaqy. Penulis tidak bermaksud mewajibkan para da'i untuk memasuki jama'ah tarikat tertentu, tetapi lebih mengarah pada arti pentingnya nilai-nilai sufistik bagi seorang da'i dalam menghadapi masyarakat di era global. Namun demikian, mengingat tidak sedikit para pemikir muslim yang mengkritik keberadaan dan keabsahan tarikat dalam Islam, maka maksud dari pentingnya tasawuf bagi da'i lebih dimaksudkan sebagai tasawuf yang positif.

\section{Dakwah Terapetik}

Untuk dapat mengatasi problem atau penyakit manusia modern, Rakhmat (2003) menyarankan agar para da'i dapat melakukan gerakan dakwah yang terapetik (bersifat menyembuhkan). Lebih jauh Rakhmat menilai bahwa dakwah harus dapat bersifat menyembuhkan, karena dakwah bukan semata-mata memberikan wawasan kognitif tentang keislaman. Dakwah bukan pula hanya bersifat menghibur, melupakan persoalan, dan menghilangkan tekanan psikologis. Lebih jauh dari itu dakwah harus dapat membantu orang-orang modern dalam memahami dirinya. Dakwah harus pula dapat membimbing umat untuk memahami realitas, memaksimalkan potensi yang mereka miliki, dan mengembangkan

${ }^{5}$ Lihat M. Quraish Shihab, Logika Agama: Kedudukan Wahyu \& Batas-batas Akal dalam Islam, (Jakarta: Lentera Hati), 2005, hal. 155 
kepribadian. Di samping itu, berkaitan dengan problem keterasingan diri sebagai akibat adanya penyakit adaptasi yang diidap oleh manusia modern, dakwah harus diarahkan pula agar dapat mengembalikan orang pada dirinya. Pengembalian pada sang diri hanya dapat dilakukan dengan mendekatkan diri kepada Sang Khaliq, Allah SWT. ${ }^{6}$

Untuk itu dakwah dapat digali dari metode para sufi dalam mendekatkan diri serta membimbing muridnya untuk dekat kepada Allah. Latihan-latihan keruhanian (Riyadlah) adalah contoh teknik yang dapat digunakan dalam melakukan tindakan-tindakan terapetik dalam dakwah. Dakwah Terapetik adalah dakwah yang juga bersifat sufistik. Dengan kata lain, Dakwah Terapetik merupakan pengembangan dari istilah Dakwah Sufistik. Dakwah Sufistik adalah dakwah dengan pendekatan tasawuf, yaitu dakwah yang lebih menekankan aspek esoterik (batiniah) ajaran Islam, ${ }^{7}$ tanpa meninggalkan aspek eksoteriknya (syari'ah). Dakwah terapetik dibangun dan digali dari semangat dan tradisi kaum sufi dalam menjalankan ajaran Islam. Mereka memahami dan menjalankan syari'at Islam secara integral antara aspek aqidah, ibadah, dan akhlak.

Hadirnya kajian-kajian dengan materi tasawuf menurut Kautsar Azhari Noer, sebagaimana dikutip oleh Rosyidi, perlu disambut secara positif, karena selama ini aspek ini tidak banyak tersentuh oleh para da'i dan mubaligh. Akibatnya jiwa masyarakat muslim menjadi kering dan gersang, sehingga tidak heran banyak ditemukan adanya orang beragama, tetapi akhlaknya rendah. Kejahatan seperti tindakan korupsi justru malah dilakukan oleh orang yang terdidik, beragama, bahkan bertitel haji. Jika ditilik lebih jauh gejala ini dapat terjadi mungkin karena akibat adanya kesalahan dalam keberagamaan masyarakat. Seorang muslim dianggap soleh kalau dia sudah melaksanakan kewajiban formal agama, seperti shalat, puasa, zakat, dan pergi haji (aspek syari'at), sementara aspek

\footnotetext{
${ }^{6}$ Rakhmat, Islam......hal. 70

7stilah Dakwah Sufistik dimunculkan oleh Jalaluddin Rakhmat untuk membedakannya dengan Dakwah Fiqhy, yaitu dakwah yang lebih berorientasi pada materi fiqih (eksoterik). Kang Jalal, demikian dia biasa disapa, memandang perlu diwacanakannya dakwah sufistik, karena melihat keberagamaan masyarakat muslim Indonesia terlalu fiqih oriented. Umat Islam sering berantem gara-gara persoalan fiqih. Di samping itu, Kang Jalal juga memunculkan slogan "dahulukan akhlakdi atas fiqih". Lebih jauh baca buku Rosyidi, Dakwah Sufistik Kang Jalal, (Jakarta : KPP Paramadina), 2004
} 
budi pekerti (akhlaq) kurang diperhitungkan. Padahal untuk menjadi muslim yang utuh diperlukan dua jalan, yaitu jalan syari'at dan tharikat, yang akhirnya akan mengantarkan manusia kepada tujuan hakikat, yaitu Tuhan. ${ }^{8}$

Gejala keterpisahan aspek esoterik (bathiniyah) dari aspek eksoteriknya (lahiriah) dan dampaknya bagi problem mental-spiritual umat dapat diamati dari sebuah contoh, yaitu tentang pengamalan sholat. Menurut Abu Sangkan (2007), dalam pemahaman masyarakat kebanyakan, selama ini shalat dianggap sebagai hal yang memberatkan bagi pelakunya, karena mereka tidak mengetahui dan merasakan ketinggian nilai spiritual yang dikandungnya. Shalat lebih merupakan kerjaan rutin dan menjemukan, sehingga tidak membuat hati lebih tenteram bagi yang melakukannya. Shalat tidak mampu menjadi penolong mereka di saat menghadapi perbagai persoalan yang meresahkan dalam hidup ini. Shalat tidak memiliki greget yang mampu mempengaruhi mental mereka untuk menjadi lebih baik dan menyenangkan.

Padahal semua orang memiliki kemampuan batiniah sebagai bekal dalam menghadapi berbagai tantangan dalam menjalani kehidupan. Hanya saja umat Islam tidak serius dalam menggali dan mengembangkan potensi ini. Akibatnya mereka merasa kebingungan ketika ditimpa persoalan hidup dan mudah mengalami kegelisahan dan kecemasan. Kondisi semacam ini, apabila dibiarkan akan menimbulkan sakit secara psikis, misalnya depresi. Kemampuan dan potensi untuk mengatasi tantangan ini sebenarnya dapat digali dan dikembangkan melalui ibadah shalat. Hanya saja, lanjut Abu Sangkan, umat Islam kebanyakan sewaktu mendapatkan pelajaran shalat saat kecil, mereka tidak diajarkan bagaimana meraih khusyu'. Pelajaran shalat hanya ditekankan pada syarat, nukun, bacaan dan gerakan yang cenderung tanpa ruh. Sampai-sampai pada saat Ramadhan tiba, berlangsulah apa yang disebut perlombaan adu cepat dalam melaksanakan shalat tarawih. Mereka akan mencari imam eksekutif yang bisa memimpin shalat dengan secepat-cepatnya. ${ }^{9}$

Lukisan kejadian tersebut membawa sebuah kesimpulan bahwa dakwah umat Islam selama ini, misalnya dalam kasus ibadah shalat, masih

\footnotetext{
${ }^{8}$ Ibid, hal. $48-49$

${ }^{9}$ Abu Sangkan, Pelatihan Shalat Khusyu': Shalat sebagai meditasi tertinggi dalam Islam,(Jakarta: Shalat Centre \& Baitul Ihsan), 2007, hal.3
} 
terlalu menekankan sisi eksetoriknya (fiqih oriented). Sisi khusyu' (esoteriknya) gagal atau belum dapat ditanamkan (didakwahkan ) secara efektif. Tidak heran jika kemudian ibadah shalat yang telah diamalkan oleh umat Islam sebanyak 5 waktu ( shalat wajib) dan ditambah shalat sunnat belum memiliki manfaat sebagaimana harapan Allah dalam beberapa ayat Al Qur'an berikut ini :

"Sesungguhnya beruntunglah orang-orang beriman ( yaitu) orang-orang yang khusyu' dalam shalatnya " 10

"... dan dirikanlah shalat untuk mengingat Aku " 11

"Jadikanlah sabar dan shalat sebagai penolongmu. Dan sesungguhnya yang demikian itu sungguh berat, kecuali bagi orang-orang yang khusyu'. 12

Ayat-ayat di atas mengisyaratkan bahwa dengan shalat, seorang akan mendapatkan kebahagiaan, baik dunia maupun akhirat. Orang merasa bahagia jika dapat menjalani hidup ini dengan mudah atau mendapatkan pertolongan jika menghadapai kesulitan. Kebahagiaan itu bisa diperoleh karena shalat juga membantu pelakunya untuk selalu memiliki kesadaran siri akan prinsip dan tujuan hidupnya, yaitu Allah (dzikir) dan kesadaran ini akan menuntun dirinya untuk selalu dapat berbuat baik (berbudi pekerti) dalam hidup. Hanya saja shalat yang akan mendatangkan kebahagiaan itu adalah shalat yang khusyu'. ${ }^{13}$

Dari materi dakwah (pelajaran) shalat tersebut dan pelajaran yang dikandung dalam ibadah-ibadah lain seperti dzikir, puasa, zakat, haji, sedekah dan lain-lain, bagi umat Islam yang dapat melakukannya dengan baik, memahami secara integral berbagai dimensinya (esoterik dan eksoterik), mereka akan mendapatkan efek dan manfaat yang besar dalam hidupnya. Salah satu efek atau manfaat tersebut adalah efek terapetik (menyembuhkan) yang ada dalam masing-masing ajaran (ibadah) tersebut.

\footnotetext{
${ }^{10}$ Q.S. 23: 1-2

${ }^{11}$ Q.S. $20: 14$

${ }^{12}$ Q.S. $2: 45$

${ }^{13}$ Kebahagiaan bisa dimaknai secara material (lahiriah-dunia) dan secara immaterial (ukhrowi-ruhaniah). Para pakar kecerdasan menyatakan bahwa orang yang akan sukses dan bahagia adalah mereka yang memiliki kecerdasan intelektual, emosional, dan spiritual. Bahkan dua yang terakhir yaitu kecerdasan emosinal dan spiritual lebih berperan dalam kesuksesan manusia dibandingkan dengan kecerdasan intelektual. Berbagai amalan ibadah dalam agama sejatinya lebih banyak mengasah kecerdasan emosional dan spiritual.
} 
Hal inilah yang harus menjadi agenda para da' $i$ di jaman modern ini. Mereka dituntut agar dapat mengembangkan dakwah akan membantu umat supaya dapat memahami dan melaksanakan ajaran Islam secara benar, sehingga dapat meraih berbagai manfaat sebagaimana telah diisyaratkan dalam $\mathrm{Al}$ Qur'an. Salah satu pendekatan yang perlu dilakukan adalah dakwah terapetik

Dakwah terapetik merupakan sebuah tawaran solusi bagi kehidupan umat manusia, sejak jaman dulu sampai jaman modern, bahkan pasca modem . Dakwah terapetik mencoba menekankan sisi-sisi yang selama ini kurang ditonjolkan dari fungsi agama bagi kehidupan, yaitu fungsi terapi, sebagai penyembuh bagi jiwa-jiwa pemeluknya.

\section{Fungsi Agama sebagai Terapi}

Pada dasarnya pijakan dakwah terapetik dapat ditelusuri dari fungsi agama sebagai syifa' ( penyembuh), sebagaimana dapat kita baca dalam Al Qur'an berikut ini :

"Dan Kami turunkan dari al- Qur'an sesuatu yang menjadi penawar dan rahmat bagi orang-orang yang beriman dan al-Qur'an itu tidak menambah kepada orang-orang yang dzalim kecuali kerugian. "(Q.S. 17:82) "Hai manusia, sesungguhnya telah datang kepadamu pelajaran dari Tuhanmu dan penyembuh bagi penyakitpenyakit (yang berada) dalam dada dan petunjuk serta rahmat bagi orang-orang yang beriman" (Q.S. $10: 57$ )

Melalui dua ayat tersebut, ditambah dengan ayat-ayat lain yang senafas maknanya, Allah menegaskan bahwa al-Qur'an (baca : Islam) diturunkan dengan maksud agar dapat dijadikan sebagai pedoman, petunjuk, penyembuh, dan rahmat bagi umat manusia. Fungsi agama (Islam) sebagai terapi disimpulkan dari adanya kata syifa (penyembuh atau penawar) yang dalam kutipan ayat yang kedua di atas dilanjutkan dengan kata-kata "limaa fish-shuduur" (bagi penyakit-penyakit yang berada dalam dada). Kata "penyakit dalam dada" dapat dimaknai dengan istilah penyakit hati, penyakit jiwa, atau penyakit ruhani. Ibnu Qayyim berpendapat bahwa fungsi penawar (penyembuh) al-Qur'an sebenarnya 
bukan hanya ditujukan kepada penyakit ruhani saja, melainkan juga jasmani. ${ }^{14}$

Dalam dunia modern (Barat) dikenal adanya upaya untuk menyembuhkan jiwa, yaitu dengan psikoterapi. Namun sampai hari ini psikoterapi yang dikembangkan oleh para psikolog di Barat ternyata belum mampu membantu menyembuhkan problem-problem mental-spiritual yang diderita oleh masyarakatnya. Hal ini terjadi karena Psikologi yang dibangun tidak berangkat dari cara pandang yang utuh tentang manusia. Manusia telah direduksi sedemikian rupa sehingga hanya dilihat dari dimensi fisik dan psikis semata. Dimensi ruhaniyah yang sejatinya lebih dalam daripada istilah mental /psikis tidak diakui keberadaannya, karena tidak dapat diamati dan diukur. Pandangan agama dipandang sebelah mata karena berada pada wilayah spiritual yang tidak dapat terjangkau dengan rasio manusia. Padahal C.G. Jung mengatakan bahwa di antara semua pasien, dengan usia 35 tahun ke atas, yang datang kepadanya tidak ada seorangpun yang masalah akhirnya tidak berkaitan dengan pencarian pandangan kehidupan yang religius. Dia menyimpulkan bahwa mereka jatuh sakit karena telah kehilangan apa yang diberikan agama kepada penganutnya pada setiap abad, dan tidak seorang pun dapat betul-betul sembuh kalau tidak memperoleh kembali pandangan keagamaannya. ${ }^{15}$ Kegagalan psikoterapi Barat inilah yang kemudian memunculkan wacana tentang perlunya pengembangan psikoterapi yang berlandaskan agama, khususnya Islam.

Menurut Utsman Najati, al-Qur'an banyak mengandung prinsip dan metode psikoterapi yang sebenarnya perlu dikaji dan dikembangkan lebih lanjut oleh para psikolog muslim. Di dalam al-Qur'an terdapat kekuatan spiritual yang luar biasa dan memiliki pengaruh mendalam atas diri manusia. Ia membangkitkan pikiran, menggelorakan perasaan, menggugah kesadaran, dan menajamkan wawasan. Manusia yang telah dipengaruhi al-Qur'an akan menjadi manusia yang baru diciptakan kembali. Najati mengajak para intelektual dan khalayak untuk melihat

\footnotetext{
${ }^{14}$ Penyakit meliputi fisik dan psikis. Ibnu Qayyim menggunakan istilah penyakit hati dan penyakit badan. Baca lebih jauh pembahasan Ibnu Qayyim dalam kitabnya : alThibbun Nabawiy.

${ }^{15}$ Jalaluddin Rakhmat, Psikologi Agama Sebuah Pengatar,(Bandung : Mizan), 2003, hal. 212-213
} 
sejarah bahwa ajaran yang dibawa dan diserukan Muhammad di tengah masyarakat yang "sakit" (baca: jahiliyah) telah mampu mengubah kepribadian para pengikutnya. Ia berhasil mengubah moral, tingkah laku, dan sistem kehidupan bangsa Arab kala itu. ${ }^{16}$ Muhammad berhasil menyembuhkan jiwa-jiwa yang sakit, yaitu kaum jahiliyah. Ia melakukan dakwah terapetik.

Prinsip psikoterapi dalam al-Quran, menurut Najati, paling tidak meliputi tahapan sebagai berikut: prinsip tauhid (keimanan dan ketakwaan), pembiasaan ibadah, dan penumbuhan sikap-sikap sabar, selalu ingat kepada Allah (dzikir), dan taubat. ${ }^{17}$ Dalam bahasa yang berbeda, Ibnu Qayyim, sebagaimana dikutip oleh Syukriyadi Sambas dan Tata Sukayat, bahwa prinsip isytisyfa (upaya penyembuhan penyakit) dalam al Qur'an adalah sebagai berikut : prinsip taubat, prinsip kelembutan dan kehalusan budi, prinsip kesadaran diri, prinsip madu, prinsip rekreasi spiritual, prinsip diagnosis sebab-akibat, dan prinsip tawakkal. ${ }^{18}$

Sebuah kesalahan mendasar dari psikoterapi Barat, lanjut Najati, adalah penekanannya pada upaya penanganan yang bersifat kuratif (bertindak setelah sakit). Inilah yang menjadi persoalan. Psikoterapi Barat dibangun di atas landasan psikologi bengkel yang sangat rapuh. Berbeda halnya dengan psikoterapi yang dibangun dari cara pandang psikologi islami. Islam sejatinya bermaksud membekali pribadi-pribadi pemeluknya untuk terbiasa melakukan pendidikan atau pelatihan dirimelalui pengamalan ibadah dan akhlak terpuji dalam kehidupan sehari-hari. Dengan pengamalan agama secara konsisten, baik secara mandiri maupun berjamaah, individu muslim diharapkan akan memiliki sebuah mekanisme auto-psikoterapi, sehingga terhindar dari gangguan mental atau jika kemudian mengalaminya pun akan segera dapat menyembuhkan dirinya , sendiri.

Sekedar contoh, misalnya dalam hal ibadah puasa, Ary Ginanjar menyebut bahwa puasa adalah bentuk atau metode pelatihan dahsyat

${ }^{16}$ Ustman Najati, Al-Qur'an dan Ilmu Jiwa,(Bandung: Pustaka), 2000, Hal. 284

${ }^{17} \mathrm{Ibid}$, hal 331

${ }^{18}$ Lihat Syukriyadi Sambas \& Tata Sukayat, Quantum Do'a, Jakarta : Hikmah, 2003. hal. $166-168$, baca juga pendapat Malik B. Badri tentang prisip-prinsip psikoterapi dala Islam dalam bukunya :, Dilema Psikolog Muslim, terj. oleh Siti Zaenab Luxfiati, (Jakarta: Pustaka Firdaus), 1996 
dan sempurna yang diberikan Allah kepada hamba-Nya. Pelatihan model inilah yang sebenarnya selama ini banyak ditunggu dan dicari oleh para trainer kepemimpinan yang sedang mencari bentuk training efektif untuk melatih pengendalian emosi dan membangun kecerdasan emosi . Hanya saja, banyak umat Islam sendiri yang kurang menyadari makna dan fungsi puasa bagi kehidupannya. ${ }^{19}$

Artinya fungsi agama sebagai terapi tidak semata-mata dilakukan oleh seseorang yang ahli kepada orang lain (klien) yang bermasalah, tetapi dapat pula dimaknai bahwa orang yang beragama secara baik dapat melakukan terapi terhadap dirinya-sendiri. Demikian pula jika digunakan istilah training atau pelatihan. Pengamalan agama sebenarnya adalah sebuah bentuk training diri yang efektif. Hanya saja orang yang dapat melakukan auto-psikoterapi atau auto-training tentu adalah mereka yang memiliki pemahaman dan pengalaman keagamaan yang lebih di banding orang kebanyakan. Untuk itulah fungsi terapetik agama akan nampak dirasakan oleh umat Islam kebanyakan jika ada fasilitatornya. Mereka adalah da'i-da'i yang mampu melakukan dakwah secara terapetik, yang mampu menggali aspek-aspek terapetik ajaran Islam.

\section{Aktualisasi Dakwah Terapetik}

Dalam konteks kekinian dakwah terapetik dapat diamati dari adanya berbagai bentuk atau ragam kegiatan. Dakwah terapetik dapat berbentuk sebuah kegiatan ceramah, khutbah, mauidzah hasanah, atau tausiyah yang dibawakan oleh para mubaligh. Dakwah model ini seharusnya dapat diwarnai dengan materi yang bersifat sufistik dan terapetik. Sudah sangat dirasakan bahwa khutbah jum'at di masjid-masjid Indonesia sering tidak menarik dan menjemukan, sehingga fenomena banyaknya jama'ah yang mengantuk (tertidur) adalah pemandangan yang biasa terjadi saat jum'atan.

Dakwah terapetik dapat pula berbentuk tulisan di media massa atau buku. Kehadiran buku-buku seperti Psikologi Shalat, Shalat Khusyu', Terapi Shalat Tahajü, Kun Fayakun, ESQ, Manajemen Qolbu, dan sebagainya, menurut hemat penulis layak dikategorikan

\footnotetext{
${ }^{19}$ Ary Ginanjar Agustian, ESQ: Rahasia Sukses Membangun Kecerdasan Emosi dan Spiritual, (Jakarta: Arga), 2001, hal 220.
}

KOMUNIKA, Vol. I No. 2 Juli-Desember 2007 
sebagai dakwah yang bersifat terapetik. Dalam pengamatan penulis, buku yang mengangkat tentang tema shalat khusyu' sangat banyak di pasaran, baik yang berupa terjemahan dari kitab-kitab tasawuf berbahasa Arab, maupun hasil karya penulis Indonesia sendiri. Beberapa penerbit besar seperti Mizan misalnya, biasanya juga memiliki line khusus yang menerbitkan buku-buku ringan, populer, dan sufistik.

Di samping melalui buku, gerakan dakwah terapetik dapat dirasakan pula dengan adanya kajian -kajian tasawuf, baik di lembaga seperti Paramadina maupun di media elektronik seperi TV dan radio. Hal itu dapat dilihat pula dari adanya lembaga training atau da'i yang sekaligus menjadi trainer yang mengadakan berbagai pelatihan seperti training ESQ dan pelatihan shalat khusyu' misalnya. Berbagai pelatihan tersebut biasanya juga dilengkapi dengan buku atau VCD.

Secara khusus, dakwah terapetik dapat dilihat dari adanya kegiatan konseling, psikoterapi, atau konsultasi yang dilakukan oleh da'i-dai seperti Dadang Hawari, Yusuf Mansur, Moh. Soleh, Zakiah Daradjat, Amin Syukur, dan lain-lain. Bentuk konsultasinya biasanya bersifat langsung, tatap muka, tetapi ada pula yang membuat layanan konsultasi via media seperti SMS, internet, surat kabar, tabloid, atau majalah. Secara institusional, kegiatan bimbingan rohani pasien di rumah sakit dan lembaga pemasyarakatn (Lapas) dapat dikategorikan pula sebagai dakwah yang bersifat terapetik. Lembaga seperti LPM milik Dompet Du'afa adalah contoh ikon gerakan dakwah terapetik. Lembaga ini terkenal dengan programnya yaitu BRP (Bina Ruhani Pasien).

Di luar contoh-contoh yang telah disebutkan di atas, masih dapat ditemukan lagi adanya bentuk dakwah yang dianggap bersifat terapetik. Tulisan ini tidak bermaksud membatasi makna dakwah terapetik secara khusus saja, apalagi terjebak pada persoalan metode dan teknik berdakwah, akan tetapi lebih mengajak para akademisi dan praktisi dakwah untuk bersama-sama melihat kembali kelemahan dakwah kita selama ini. Salah satu kelemahan itu adalah sering kali da'i tidak mampu menangkap dan memahami fenomena atau gejala krisis mental-spiritual masyarakat yang menjadi medan garapannya, sehingga dakwah yang dibawakan cenderung tidak menyejukkan, tidak menyelesaikan masalah, dan tidak menyembuhkan jiwa-jiwa jama' ahnya. Para da'i perlu melakukan gerakan dakwah yang sufistik-terapetik. Untuk itu diperlukan 
penggalian dan pemahaman kembali dimensi terapetik ajaran Islam. Dimensi ini lebih banyak tersimpan dalam sisi esoterik dibanding eksoterik ajaran Islam.

\section{Penutup}

Dalam konteks kekinian Dakwah terapetik dapat pula berbentuk tulisan di media massa atau buku. Kehadiran buku-buku seperti Psikologi Shalat, Shalat Khusyu', Terapi Shalat Tahajjud, Kun Fayakun, ESQ, Manajemn Qolbu, dan sebagainya. Di samping melalui buku, gerakan dakwah terapetik dapat dirasakan pula dengan adanya kajian -kajian tasawuf, baik di lembaga seperti Paramadina maupun di media elektronik seperi TV dan radio. Secara khusus, dakwah terapetik dapat dilihat dari adanya kegiatan konseling, psikoterapi, atau konsultasi yang dilakukan oleh da'i-dai seperti Dadang Hawari, Yusuf Mansur, Moh. Soleh, Zakiah Daradjat, Amin Syukur, dan lain-lain. Secara institusional, kegiatan bimbingan rohani pasien di rumah sakit dan lembaga pemasyarakatn (Lapas) dapat dikategorikan pula sebagai dakwah yang bersifat terapetik. Lembaga seperti LPM milik Dompet Du'afa adalah contoh ikon gerakan dakwah terapetik. Lembaga ini terkenal dengan programnya yaitu BRP (Bina Ruhani Pasien).

\section{DAFTAR PUSTAKA}

Agustian, Ary Ginanjar, ESQ: Rahasia Sukses Membangun. Kecerdasan Emosi dan Spiritual, Jakarta : Arga, 2001.

Badri, Malik, Dilema Psikolog Muslim, terj. oleh Siti Zaenab Luxfiati, Jakarta: Pustaka Firdaus, 1996.

Najati,Ustman, Al-Qur'an dan Ilmu Jiwa, Bandung: Pustaka, 2000.

Qoyyim, Ibnu, al-Thibbun Nabawiy, Beirut, t.t.,

Rakhmat, Jalaluddin, Psikologi Agama Sebuah Pengatar, Bandung:

Mizan, 2003. -, Islam Aktual, Bandung: Mizan, 2003 
Sangkan, Abu, Pelatihan Shalat Khusyu': Shalat sebagai meditasi tertinggi dalam Islam, Jakarta: Shalat Centre \& Baitul Thsan, 2007.

Shihab, M. Quraish, Logika Agama: Kedudukan Wahyu \& Batasbatas Akal dalam Islam, Jakarta: Lentera Hati, 2005.

Sholeh, Moh \& Musbikin, Imam, Agama Sebagai Terapi, Yogyakarta: Pustaka Pelajar, 2005.

Syukriyadi Sambas \& Tata Sukayat, Quantum Do'a, Jakarta: Hikmah, 2003. 